\title{
Europako Ingurumen Zuzenbidearen oinarrien eta printzipioen eboluzioa eta egungo egoera: Tratatuak, Ekintza Programak eta Estrategiak
}

Asier García Lupiola*

DOI: https://doi.org/10.47623/ivap-rvap.108.2017.11

\begin{abstract}
Aurkibidea: I. Sarrera.-II. Aurreneko Ingurumen Ekintza Programak. -III. Europako Akta Bakarra eta Laugarren IEP.-IV. Maastrichteko Tratatua eta Bosgarren IEP. - V. Amsterdameko Tratatua, Lisboako Estrategia eta Seigarren IEP. - VI. Lisboako Tratatua eta Europa 2020 Estrategia.-VII. Zazpigarren IEP eta Energiaren eta Klimaren Esparrua 2030erako. - VIII. Ondorioak
\end{abstract}

\section{Sarrera}

Ingurumena babestea gizartearen kezka handienetakoa da gaur egun, are gehiago klima aldaketaren eraginek duten garrantzia ikusita. Ingurumena ez errespetatzeak sorrarazitako ondorio anitzak bezain larriak eta ingurumenaren babesa eta ekonomiaren hazkundea batzeko premia kontuan hartuta, nazioartean erronka nagusietako bat bilakatu da garapen iraunkorra. Europar Batasunean (EB) indarrean dagoen araudiak ebatzitakoaren arabera, integrazio prozesuaren funtsezko helburuetako bat da garapen iraunkorra, EBren Tratatuaren (EBT) 3. artikuluan adierazi bezala.

Dena den, Europako Erkidegoak (EEEE) eratzeko Tratatuek ez zuten printzipio hori ezarri, baina tratatu horietako erreforma desberdinei esker bilduta geratu zen azkenean EBko funtsezko testu juridikoetan - gaur egun, EBTn ez ezik EBren Funtzionamenduari buruzko Tratatuan (EBFT) ere-. Era horretan, garapen iraunkorra Europako Jatorrizko Zuzenbidearen barruan geratu zen zehaztuta, Europar Batasuneko Estatu guztientzako helburu lotesle gisa. Helburu hori lortzeko, funtsezkoa izan da Europako ingurumen politikaren garapena.

\footnotetext{
* Testu hau UPV-EHUren ikerkuntzarako laguntza jaso duen ekintzaren emaitza da (NUPV16/04: «Políticas y acciones europeas en materia de medio ambiente, cambio climático y energía»).
} 
Hori dela eta, EBren eta estatu kideen arteko eskumen partekatu bat da ingurumena (4.2. art. EBFT). Horrek esan nahi du eremu horretan bai Batasunak bai estatuek juridikoki lotesleak diren legeak egin eta egintzak burutu ditzaketela, nahiz eta Batasunak berea erabili ez duen heinean bakarrik erabili ahal izango duten beren eskumena Estatuek (2.2. art. EBFT). Gai honetan, EBk aktiboki erabili du Tratatuak ematen dion ahalmena. Izan ere, Jatorrizko Zuzenbidearekin batera, zeinak ingurumen politikaren oinarri zehatzak finkatzen dituen, egintza juridiko lotesle ugari aurkituko ditugu, oinarri horiek garatzen dituzten Batasuneko instituzioek ezarritakoak. Oinarri horiek Europako Zuzenbide Eratorria osatzen dute ingurumenaren gaietan, Europako ekintza programetan finkatutako lehentasunezko helburuak lortzeko jarraitu beharreko gidalerroak kontuan hartuta, gainera (192.3. art. EBFT).

Hala, Europako oinarrizko ingurumen araudiak eta gai horri dagozkion lehentasunezko helburuek Europaren integrazio prozesuan izan duten eboluzioa da testu honen aztergaia. Ikusiko dugunez, hasiera batean eratze Tratatuek ingurumen politikarik jaso ez bazuten ere, etapa desberdinak izan dira ondoren: aurreneko Ingurumen Ekintza Programek (IEP) eta Europako Akta Bakarrak (EAB) ingurumen politikaren oinarriak ezarri zituzten; Maastrichteko eta Amsterdameko Tratatuek indartu eta bultzatu egin zuten - bosgarren eta seigarren IEPtan agerian geratu zena-; eta Lisboako Tratatuak eta zazpigarren IEPk, orain indarrean dauden Europako Ingurumen Zuzenbidearen helburuak, printzipioak eta gidalerroak biltzen dituzte, eta horien artean nabarmentzen da ingurumena babesteko tresna eraginkor gisa energia politika baliatzea.

\section{Aurreneko Ingurumen Ekintza Programak}

Europako ingurumen politikak 1970eko hamarkadaren hasieran du bere sorburua, EEEEn eratze Tratatuek ez baitzuten arautu politika horren ezarpena. Kontuan hartu behar da garai hartan Erkidegoa osatzen zuten sei estatuak aplikatzen ari ziren arauak, ingurumenari lotutakoak, oztopo bat izan zitezkeela merkantzien trukerako eta zirkulazio askerako(1). Horregatik, 1971n, Batzordeak aurreneko dokumentua onetsi zuen gai horren inguruan, Merkatu Erkidearen garapena egokiro arautzeko helburuz ingurumena kontuan hartzeko premiaren aurrean eta Erkidegoaren helburuekin bateragarria zela aintzatetsiz(2). Ikus daitekeenez, «merkataritza-bloke bat eratzeak (...) ingurumen kalitate maila desberdinetako herrialdeek osatuak, eraman zi-

(1) 1968an, aurreikusitakoa baino bi urte lehenago, merkantzien zirkulazio askea jarri zen abian EEEEko estatuen artean. Hala, merkataritza askerako gune bat ezarri zen, Merkatu Erkidea izango zenaren aurreneko pausoa, alegia.

(2) EUROPAR BATZORDEA, Première communication sur la politique de la Communauté en matiére de l'environnement, Europako Erkidegoko Aldizkari Ofiziala - JOCE C 19, 1972. 
tuen gai horretan Erkidegoko estatuek jarraitu beharreko lerro nagusiak taxutzeko garaian nazioz gaindiko ikuspegi bat planteatzera» (3).

Nolabait ere, ingurumenaren inguruan iritzi publikoak erakusten hasitako interesari erantzun nahi zioten EEEEk, nazioarteko mugimendu ekologista sortu berriaren jardunak piztutakoari, nazioarteko agendan hartu zuen lekua kontuan izanik gainera. Izan ere, 1972ko Ingurumenari buruzko Nazio Batuen Konferentzian Stockholmeko Deklarazioa atera zen jendaurrera, oraingo eta etorkizuneko belaunaldien onurarako baliabide naturalak iraunarazteko premia planteatzen zuena. Gauzak horrela, EEEEtako herrialdeetako Estatu eta Gobernu Buruek deklarazio politiko bat igorri zuten 1972ko urriko Parisko Gailurrean, bizi kalitatea hobetzeari eta ingurumena eta bertako baliabideak babesteari lotutako hazkunde ekonomiko baten premia aitortu zuena. Deklarazio horretan Europako ingurumen politika izango zenaren oinarrizko printzipioak finkatu ziren, eta instituzioei eman zitzaien ingurumen ekintza programa bat lantzeko ardura.

Lehenengo IEP 1973ko azaroaren 22an hartu zuen EEEEtako Kontseiluak, helburu nagusitzat zuena Erkidegoko estatuetako bizi kalitatea eta ingurumena hobetzea. Hala, hortik abiatuta erabaki ziren helburu zehatzak: airearen kutsadura eta uretan egiten ziren isurketak gutxitzea; baliabide naturalak zentzuz erabiltzea; oreka ekologikoa iraunaraztea; garapena bideratzea ingurumen kalitatearen eskakizunen arabera; ingurumenaren arazoei konponbide bateratuak proposatzea nazioarteko erakundeen esparruan, gai horretan nazioarteko solidaritatea lortzeko helburuz. Xede horiek lortzeko, Programak zenbait printzipio ezarri zituen, ingurumen politika egituratu behar zutenak: prebentzioa eta kalteak saihesteko neurriak hartzea; ingurumen inpaktuaren ebaluazioa; ezagutza zientifikoak eta teknikoak hobetzea; "kutsatzen duenak ordaintzen du» printzipioa; ingurumena babesteko iritzi publikoa sustatzea.

Aurreneko pauso itxaropentsu bat izan bazen ere, Lehen Programa horrek kontrako testuinguru bati aurre egin behar izan zion, petrolioaren krisiak eta ondoriozko atzeraldi ekonomikoak erasandakoari, alegia. Gainera, azpimarratu beharra dago ez zituela zehazten aurreikusitako xedeak betetzeko behar ziren baliabideak edo tresnak.

Bigarren IEP 1976ko maiatzaren 7an hartu zuen Kontseiluak. Aurrekoaren jarraipentzat hartzen da, zeren eta biek «finkatu zituzten Erkidegoan ingurumen interesak babesteko oinarriak eta ezarri zuten helburu nagusitzat baliabide naturalen zentzuko erabilera, garapen ekonomikoarekin bateragarria izango zena» (4). Bigarren Programaren helburu bereziak hauek

(3) MUÑOZ DE BUSTILLO, Rafael eta BONETE, Rafael, Introducción a la Unión Europea: un análisis desde la economía, Alianza, Madril, 2002, 295 orr.

(4) CUENCA GARCíA, Eduardo, Economía de la Unión Europea, Pearson-Prentice Hall, Madril, 2007, 419 orr. 
ziren: ingurumen gaietan informazio prozedura bat abian jartzea eta «kutsatzen duenak ordaintzen du" printzipioaren aplikazio eraginkorra, hori guztia prebentzio neurriak hartzeko premia azpimarratuz, eta horretarako ingurumen inpaktuaren azterlanak egiteko prozedura egokiak ezarriz.

Hala, Eratze Tratatuek estatu kideetarako ingurumen erregulazio bateraturik barnean hartzen ez zutenez, lehendik zeuden legeria nazional desberdinek aldatu zituzten lehia askearen arauak. Egoera horren ondorioz, aurreneko bi Programek Zuzentarau ugari onetsi zituzten legeria estatalak hurbiltzeko uraren eta airearen kutsadura, zarata eta hondakinak bezalako gaietan, eta era horretan ezarri ziren ingurumen kalitatearen hasierako estandar erkide batzuk. Horiek gabe, «ezinezkoa izango zen merkatuaren mekanismoetan oinarritutako jarduketa erkideak ondoren planteatzea» (5).

1980ko hamarkadan zehar, ingurumenaren babesak gero eta protagonismo handiagoa hartu zuen EEEEn barruan. Eta horretan eragin nabaria izango zuen gai honi dagokionez Alemaniak bereganatutako aitzindaritzak, hark bultzatuko baitzuen Erkidegoetatik neurri berriak hartzera, Estatu guztiek norabide beretik aurrera egin zezaten saiatzeaz gainera (6). Hala, Hirugarren IEP izan zen horren aurreneko emaitza, 1983ko otsailaren 7ko Kontseiluaren Ebazpen bidez onetsia. Eta, berriro ere, aurreneko bi Programek hasitako lerroari jarraitzea izango zen bere helburu nagusia. Dena den, aldaketa kualitatibo nabarmenak barneratu zituen, ondorengo ekintza planen edukian eragina izango zutenak.

Era horretan, baliabide natural desberdinei lotutako ingurumen kalitate estandarrak finkatzeko prozesua jarraitu zuten zuzentarauekin batera, politika erkideek aurrera eramandako ingurumen inpaktuaren kontrola areagotu zen, proiektu handiek ingurumenaren gainean izango zuten ondorioak aztertzeko eskakizuna orokortzea ekarri zuena, bereziki Nekazaritza Politika Erkideari eta azpiegituretako inbertsioei zegokienez. Hala, prebentzioaren printzipioa sendotu zen, ingurumen estrategia global bat abiarazteko oinarritzat hartuko zena. Aldi berean, "kutsatzen duenak ordaintzen du» printzipioaren profil zehatza finkatu zen, leheneratze betebeharra barneratuz. Azkenik, aipatzekoa da gainera gauzatu egin zela «enfasi berritu bat jarreren aldaketan (sentsibilizazioa-informazioa-hezkuntza)» (7) eta ingurumen gaie$\tan I+G$ ahaleginei zuzendutako laguntzak sortu zirela.

EEEEtako agintariak jabetuta zeuden gune eta baliabide naturalak behar bezala babestu eta kudeatzeko premiak iritzi publikoaren artean adierazten zuen gero eta kezka handiagoaz. Horregatik, ekosistema natu-

(5) Ibídem, 420 orr.

(6) ALBERTON, Mariachiara, «Environmental Protection in the EU Member States: Changing Institutional Scenarios andTrends", L'Europe en formation, 363 zenbakia, 2012, 290 orr.

(7) MUÑOZ DE BUSTILLO, Rafael eta BONETE, Rafael, op. cit., 298 orr. 
ralak hobeto zaindu eta babestera bideratutako ekintzak ezarri ziren, baita bereziki sentikorrak diren eskualdeen kudeaketa integratu bat ziurtatzera bideratutakoak ere, ingurumenari dagokionez garrantzi handikoak izategatik edo ekonomiaren hazkunderako erakargarriak zirelako.

Hirugarren IEPren ekarpen handienetako bat izan zen programa horretatik abiatuta identifikatu zela politika guztietarako ingurumena babesteko helburu nagusia. Programaren aplikazioaren garapenean zehar ziurtatu ahal izan zenez, ingurumenari buruzko kontsiderazioek eragina zuten politika zehatz batzuetan - nekazaritza, energia, industria, garraio edo turismo politiketan, besteren artean - eta beraz, beharrezkotzat jotzen zen ingurumena babesteko estrategia global bat formulatzea. Horrek adierazi zuen, ingurumen politika espezifikoan ez ezik, gainerako politiketan ere barneratzen zirela ingurumen kezkak eta, zehazki, arazo sozioekonomikoen konponbideari lotzen zitzaizkiola ingurumeneko ekintzak. Hala, aurrerapen nabarmena igartzen hasi zen hasierako egoeraren aldean, ordutik aurrera gai honi lotutako arazo nagusia ez baitzen gehiago izango "estatu kideen arteko desadostasuna, merkatu erkidearen jardun egokian eragina izan zezakeena, araudi desberdinak zirela eta. Hala, ekonomia kontzeptuan bertan barneratu zen harrez geroztik ingurumenaren kalitatearekiko kezka» (8).

Kontsiderazio haiek Europako Akta Bakarra (EAB) berekin ekarri zuten negoziazioetan kontuan hartu ziren, eta hemen aztertzen ari garen gai honetan testu horrek adierazi zuen aurrerabidearen oinarria izan ziren.

\section{Europako Akta Bakarra eta Laugarren IEP}

EAB, 1986an negoziatua eta sinatua, 1987ko uztailaren 1ean sartu zen indarrean, eta Erkidegoak eratzeko Tratatuak erreformatu zituen Europaren integrazioari bultzada berri bat emateko helburuz. Berrikuntza instituzional nabarmenak ekarri eta Europako Erkidegoaren (orain singularrean, EE) barne merkatua abian jartzeko beharrezko neurriak ezartzeaz gain, EABk politika berrietan egituratutako gaien erregulazioa barneratu zuen eremu erkidean, ingurumenarekin gertatu zen bezala(9). Testu horrekin, EBko buruzagiak erantzun bat bilatzen hasi ziren herritarrek planteatutako erronken aurrean, kontuan izanik herritarrek ingurumenaren alde eragindako presioa

(8) CUENCA GARCÍA, Eduardo, op. cit, 421 orr.

(9) EABren helburuetako bat zen Europako merkatu erkidea behin betiko eratzea. Zentzu horretan, testuak, kontzeptu horretatik harago, nozio berri bat barneratu zuen: "barne-merkatua». Nozio horrek "barne-mugarik gabek espazio" bat adierazten zuen, non merkantzien, pertsonen, zerbitzuen eta kapitalen zirkulazio askea bermatuta geratzen zen Tratatuaren bitartez. Hala, erabat bateratutako espazio bat bezala agertu zen barne-merkatua, barne-aduanak eta aduana horiei zegozkien kontrol teknikoak, fisikoak, fiskalak eta monetarioak ezabatzean. Oztopo horiek guztiak ezabatzeak ingurumenekoak ere ezabatzea ekarri zuen berekin, beraz. 
gero eta handiagoa zela hondamendi ekologiko gero eta izugarriagoen aurrean, eta bereziki Txernobylen gertatutako hondamendiaren aurrean(10). Hala, EAB mugarri bat izan zen Europako Erkidegoak ingurumenaren babesean beteko zuen zereginaren eboluzioan, gai honetan araudi espezifiko bat eta subsidiariotasun printzipioa barneratu baitzituen, merkataritza, nekazaritza, energia edo ikerketa bezalako beste gai batzuekin lotuz, gainera(11).

Europako Erkidegoa bezalako merkataritza bloke baten eraketak, ingurumenaren babesari zegokionez eskakizun maila desberdinak zituzten herrialdeek osatua, jarraitu beharreko lerro nagusien diseinuan nazioz haraindiko ikuspegi bat hartzea komeni zela planteatzera eraman zituen estatu kideak. Gai horretan, EABrekin gainditu nahi ziren merkantzien zirkulazio askerako sor zitezkeen oztopoak. Eta arazo haiek kontrakoak izan zitezkeen. Hala, batetik, hondakinak bezalako produktu arriskutsuen zirkulazio askeak, ingurumenean duten inpaktuarekiko gutxieneko bermerik gabe, edukiez gabetu zitzakeen eremu horretako eskakizun nazionalak, produktu nazionalen eta Erkidegoko beste estatu batzuetakoen artean bereizi ezin izatean. Bestalde, araudi nazionalen ingurumen eskakizun haiek distortsio nabarmenak sorrarazi zitzaketen merkataritzan xede protekzionistekin erabiliz gero. Arazo horiez gain, kontuan hartzen zen dumping ekologikoko egoerak ez ote ziren sortuko, eskakizun gutxiagoko ingurumen araudiak zituzten herrialdeek eskainiko lituzketen abantaila konparatiboetatik eratorriak. Aldi berean, horrek eramaten zuen pentsatzera ekoizpen jarduerak ingurumenean duen inpaktuak muga nazionalak gainditzen dituenean jardunbide multinazionala eraginkorragoa izango litzatekeela.

Akta Bakarrak Ingurumenari buruzko VII. Titulua barneratu zuen Europako Erkidegoa eratzeko Tratatuaren (EET) Hirugarren Zatian. Hala, EABk «EEren jatorrizko zuzenbidean ezarri zuen ingurumenaren kontserbazioa eta adierazi zuen atxikita zegoela garapen ekonomikoari eta sozialari, bizi kalitateari eta Europako beste politika batzuen iraunkortasunari» (12). Ikusten denez, "garapen ekonomikoaren dimentsio ekologiko bat lortzeko programak prestatzea eta abian jartzea zen asmoa» (13).

Titulu berria osatu zuten hiru artikuluetatik (orduan $130 \mathrm{R}, 130 \mathrm{~S}$ eta 130T artikuluak, EETrenak) Ekintza Programetan landu izan ziren funtsezko ideiak bildu zituen lehenak. Hala, ingurumenari dagokionez, ondokoak finkatu ziren Erkidegoaren helburutzat: ingurumenaren kalitatea zaintzea, babestea eta

(10) WOOD, David M. eta YESILADA, Birol A., The Emerging European Union, New York, Pearson Longman, 2006, 172 orr.

(11) GUSEV, Alexander S., "Climate Change Issues in a Transatlantic Context", L'Europe en formation, 369 zenbakia, 2011, 80 orr.

(12) NIETO SOLÍS, José Antonio, La Unión Europea. Una nueva etapa en la integración económica de Europa, Pirámide, Madril, 2005, 217 orr.

(13) CUENCA GARCÍA, Eduardo, op. cit., 412 orr. 
hobetzea; pertsonen osasuna babesten laguntzea; eta baliabide naturalak zuhurki eta zentzuz erabiltzea. Helburu horiek lortzeko, Erkidegoaren ekintzak printzipio hauetan oinarritu behar zuen: prebentziorako ekintzak, ingurumenarekiko erasoak zuzentzeko ekintzak (lehentasunez iturrian bertan) eta «kutsatzen duenak ordaintzen du» printzipioa. Era berean, aginduak zehaztu zuen «ingurumena babesteko eskakizunak Erkidegoko gainerako politiken osagai izango dira», Hirugarren Ekintza Programan zehaztu bezala.

Bestalde, Erkidegoaren oinarrizko araudi berriak ezarri zuenez, ingurumeneko bere ekintza lantzean ondokoak hartuko ziren kontuan: eskueran dauden datu zientifikoak eta teknikoak; ingurumenaren baldintzak Erkidegoko eskualde desberdinetan; ekitetik edo ez ekitetik sor daitezkeen abantailak eta kargak; Erkidegoaren garapen ekonomikoa eta soziala oro har, eta bertako eskualdeen garapen orekatua.

Azkenik, nabarmendu beharra dago EABk subsidiariotasun printzipioa ezarri zuela gai honetan jarduteko erreferente gisa. Horren arabera, Erkidegoak ingurumeneko ekintza aurrera eramango du Europa mailan helburuak baldintza hobeagotan lortu behar badira, estatuek erabakiak bakarka hartu baino.

EAB indarrean sartu eta handik gutxira, 1987ko urriaren 19an, Laugarren IEP onesten zuen Ebazpena hartu zuen Kontseiluak (14). Bere aurrekariaren estrategia globalaren barruan inskribatzen zen, baina izaera osatuagoa eta hedakorragoa zuen, EABk ezarritako oinarrizko araudi berritik eratorria. Hala, Hirugarren Programaren aplikazioan zehar hasitako lerroari jarraitu zion, hau da, ingurumenaren alderdiak beste politika erkidego batzuetan barneratzeari, eta aurreneko bi Programen betearazpen mailaz arduratu zen (15).

Aldi berean, Laugarren Programak ingurumen politikaren garapen egonkorra lortzeko tresna egokiak sortzeari ekin zion. Hala, elementu antolatzaileen artean nabarmentzekoa da Kopenhagen egoitza duen Europako Ingurumen Agentziaren sorkuntza 1990ean(16) eta elementu finantzarioen artean ingurumena babesteko LIFE finantzaketa tresnaren sorkuntza 1992an.

(14) Erabakia 87/C 328/91 zk., Europako Erkidegoetako Kontseiluarena, 1987ko urriaren 19koa, Europako Erkidegoko Aldizkari Ofiziala C 289, 1987/10/29.

(15) Horri dagokionez, neurriak proposatu ziren Erkidegoko estatu desberdinetan helburuak zein neurritara betetzen ziren ziurtatzeko, besteren artean: ingurumen hezkuntza sustatzea, ingurumen kalitateari buruzko arau zorrotzagoak ezartzea eta ingurumenari lotutako gaiei buruzko informaziorako sarbide orokorra.

(16) Erregelamendua (EEE) 1210/90 zk., 1990eko maiatzaren 7koa, Kontseiluarena, Europako Ingurumen Agentzia eta Ingurumenari buruzko Informazio eta Behaketarako Europako Sarea sortzen dituena. Testu horrek aldaketak izan ditu behin baino gehiagotan, eta 2009an onetsi zen indarrean dagoen bertsio kodetua: Erregelamendua (EE) 401/2009 zk., Europako Parlamentuarena eta Kontseiluarena, 2009ko apirilaren 23koa, Europako Ingurumen Agentziari eta Ingurumenari buruzko Informazio eta Behaketarako Europako Sareari buruzkoa, Europako Erkidegoko Aldizkari Ofiziala 126/13 L. 


\section{Maastrichteko Tratatua eta Bosgarren IEP}

Ingurumen gaietan ekintzak garatzean eta Erkidegoaren araudian ingurumen helburuak progresiboki gehitzean onuragarria izan zen estatu aurreratuenen aldez aurreko esperientzia hazkunde ekonomikoa eta ingurumenarekiko errespetua bateragarriak izatea lortzeko zereginean. Danimarkakoa zen kasu nabarmenena. Herrialde horren ingurumen kezka 90eko urteen hasieran Erkidegoko kide izateko negoziazioetan ziharduten iparraldeko beste bi herrialdeenaren antzekoa zen. Maastrichteko Tratatua berekin ekarriko zuten negoziazioetan Suedia eta Finlandia behatzaile izateak erraztu egin zuen ingurumena Gobernu arteko Konferentzian aztergai izatea. Gainera, ezin dugu ahaztu Erkidegoko estatuen ordezkaritzek 1992an izango ziren eztabaiden prestakuntzan egin zituzten lanen eragina Nazio Batuek Rio de Janeiron antolatutako Ingurumenari buruzko Gailurrean (Lurraren Gailurra deritzona).

1992ko otsailaren 7an Europar Batasunaren Tratatua (EBT) sinatu zen Maastrichten, baina aurreikusitakoa baino beranduago sartu zen indarrean -1993ko azaroaren 1ean-, tratatua berresteko arazoak izan zirelako. Gure aztergaiari dagokionez, Tratatu berriak hau ezarri zuen Batasunaren helburuen artean: «aurrerabide ekonomiko sozial orekatua eta iraunkorra sustatzea» (2. art. EBT). Helburu hori EETren 2. artikuluan egin zen erreforman gauzatu zen, adierazi zenean Erkidegoak xedetzat izango duela «ingurumena errespetatuko duen hazkunde iraunkorra eta ez inflazionista» sustatzea.

EETn jasotako ingurumen araudiak - XVI. Titulua izango zena- zenbait aldaketa izan zituen. Lehenik, ingurumenaren gaietan EABk zehaztutako hiru helburuei nazioartean hartuko ziren neurriak sustatzearena gehitu zitzaien, eskualdeetan edo munduan gertatzen ari ziren ingurumen arazoei aurre egiteko, baita gai horretan babes maila handia lortzearena ere. Bigarren, Batasunaren ekintzak oinarritzat hartu behar dituen printzipioei zuhurtasunarena gehitu zitzaien. Hirugarren, kontsulta prozeduraren ordez, ingurumenari dagokionez hartu beharreko erabaki gehienetarako lankidetza prozedura ezarri zen.

Azkenik, Maastrichteko Tratatuak ingurumena babesteko baliabide erkideez hornitzeko aukera zabaldu zuen. Eremu horretan aspaldi batez agerikoa zen kontsiderazio bat hartu zen kontuan, Europar Batasuna ekonomiaren garapen maila desberdina zuten herrialdeez osatuta egotean honakoa aintzat hartzekoa: «ingurumenari dagokionez gutxieneko batzuk bermatzeko premia planteatzen denean, ezinbestekoa da konpentsazioren bat abian jartzea, garapen maila baxuagoa duten herrialdeei lagunduko diena eta, hala eta guztiz ere, herrialde horien garapen mailarako ingurumen araudi aurreratuegia hartzea adieraziko lukeena»(17). Egoera horren au-

(17) MUÑOZ DE BUSTILLO, Rafael eta BONETE, Rafael, op. cit., 297 orr. 
rrean, diru-laguntzen funtsak sortzea planteatu zen herrialde horiek ingurumenarekiko errespetu maila jakin batzuk hartu ahal izateko, hain zuzen ere herrialde garatuagoei dagozkienak. Hala, goian aipatutako LIFE tresnarekin batera, ingurumena babesteko bideratzen hasi ziren neurri handi batean Funts Estrukturalen eta Kohesio Funtsaren ahalmen finantzarioa.

Maastrichteko Tratatuaren ondoren, ingurumeneko Bosgarren IEP iritsi zen, "Garapen iraunkor baterantz» izenekoa. Zehazki, ekintza programa hori onetsi zuen Ebazpena 1993ko otsailaren 1ean hartu zuen Kontseiluak (18) eta hamar urteko aldira arte luzatzen zuen bere indarraldia. Bere helburu nagusia zen Europako hazkunde eredua garapen iraunkorrerantz gutxika bideratzea, ekoizpen eta kontsumo ereduak aldatuz. Ingurumenaren eta jarduera eta garapen ekonomiko eta sozialaren planteamendu berri baterako esparru egoki bat sortzea zen asmoa. Era horretan, ingurumen politika horizontal bat ezarri nahi izan zen Batasunean, hau da, «bere edukia Batasunaren eta bertako Estatu guztien ekintza guztietara zabaltzea, ahal den neurrian, ekosistemetan eta herritarren bizi kalitatean ondorio larriak saihestearren» (19).

Bosgarren IEPk 1990ean Dublinen egindako Europako Kontseiluaren Deklarazioa zuen oinarritzat, non garapen iraunkorra biltzen zuen Europako Erkidegoaren helburutzat, ondoren Maastrichteko Tratatuak eragindako erreformarekin ezarrita geratuko zena. Hala, honela definitu zuen garapen iraunkorra: orainaldiko premiak betetzen dituen garapena, baina betiere etorkizuneko belaunaldiek beren premiak betetzeko izango duten ahalmena arriskuan jarri gabe.

Programaren helburu espezifikoak lehentasunezko bost sektoretan zehazten ziren: industria, energia, garraioa, nekazaritza eta turismoa. Industriaren arloan, hauek ziren helburu zehatzak: enpresetan baliabideen zentzuzko kudeaketa garatzea; kontsumitzaileei informazio gehiago ematea; fabrikazio prozesuei eta produktuei buruzko arau erkideak ezartzea lehiaren distortsio posibleak saihestuz, barne-merkatuaren osotasuna zainduz eta Europako lehiakortasuna iraunaraziz. Energiaren arloan: energiaren eraginkortasuna hobetzea; erregai fosilen kontsumoa gutxitzea; energia berriztagarriak sustatzea. Garraioaren arloan hauek ziren lortu beharreko helburuak: batetik, azpiegituren, ekipamenduen eta erregaien kalitatearen kudeaketa hobetzea, eta bestetik, garraio publikoak garatzea. Nekazaritzak, Nekazal Politika Erkidearen erreformaz gain, hau zuen helburu: gero eta laborantza intentsibo handiagoaren, ongarrien erabileraren eta soberakinen metaketaren ondoriozko narriadura kontuan hartzea. Azkenik, turismoaren arloan, helburuak ziren masa-turismoaren kudeaketa

(18) Erabakia 93/C 138/01 zk., Kontseiluarena, 1993ko otsailaren 1ekoa, Europako Erkidegoko Aldizkari Ofiziala C 138, 1993/05/17.

(19) NIETO SOLÍS, José Antonio, op cit., 218 orr. 
hobetzea eta turismo modu alternatiboak sustatzea informazioaren eta sentsibilizazioaren bitartez.

Helburu horiek lortzeko, Bosgarren Programak tresna ugari egituratu zituen, horien artean aipatzekoak: Ingurumen adierazleak lantzeko mekanismoak sortzea, baita emisioen eta isurketen inbentarioak ere; ingurumenari eta energiari buruzko I+G jardueretan inbertsioa handitzea; politika fiskaletan ingurumena babesteko betekizunak barneratzea eta ingurumena babesteko zerga-pizgarriak sustatzea; Funts Estrukturaletan eta Kohesio Funtsean finantzaketa handitzea, baita LIFE programan eta Enpresa Txiki eta Ertainei laguntzeko mekanismo ekonomikoetan ere; ingurumenari buruzko informazio publikoa nabarmen zabaltzea, informazio horretara heltzeko bideak erraztuz; eta neurriak hartzea hezkuntza maila guztietan (oinarrizko prestakuntza, unibertsitate eta lanbide prestakuntza) (20) .

Aldi hartan zehar, 1994an zehazki, Europako Ingurumen Agentzia hasi zen jardunean. EIA erakunde erkide gisa eratu zen, ingurumenari buruzko informazio irmoa eta independentea eskaintzeko, eta bertan, Europar Batasuneko estatu kideek ez ezik, Europako beste herrialde batzuek ere parte har zezaketen (21). Tratatuan bildutako jarraibideak betez, EIAk ingurumena hobetzeko diren erabakiak hartzeko modua erraztu nahi die Batasunari eta bertako herrialdeei, politika ekonomikoetan ingurumenari buruzko kontsiderazioak barneratuz eta iraunkortasunaren gaietan aurrera eginez(22).

\section{Amsterdameko Tratatua, Lisboako Estrategia eta Seigarren IEP}

1997ko urriaren 2an Amsterdameko Tratatua sinatu zen, eta 1999ko maiatzaren 1ean sartu zen indarrean. Kritika ugari jaso zituen testua izan arren, aitortu beharra dago ingurumenari dagokionez berritasun nabarmenak ekarri zituela, "politika horren erregulazioa era organiko eta sistematizatu batean» egituratuko zutenak(23). EBTri dagokionez, Amsterdameko

(20) Dena den, tresna horiek ez ziren nahikoa, garapen iraunkorra lortzeko beharrezkoa baitzen «Erkidego osoaren, Erkidegoko estatuen, enpresa munduaren eta herritarren jokabideak zeharo aldatzea, Batzordeak gauzatu beharreko politika ekonomikoaren tresnak baino askoz ere asmo handiagoko helburua, alegia». MUÑOZ DE BUSTILLO, Rafael eta BONETE, Rafael, op. cit., 299 orr.

(21) Gaur egun, Europar Batasuneko 28 Estatu kideekin batera, hauek dira EIAren kide: Islandia, Liechtenstein, Norvegia, Suitza eta Turkia. Hauek dira herrialde kolaboratzaileak: Albania, Bosnia-Herzegovina, Kosovo, Mazedonia, Montenegro eta Serbia.

(22) Dagozkion funtzioak garatzeko, ElAk urteanitzeko programak lantzen ditu, bere jardunean jarraitu beharreko estrategiak zehazten dituztenak, eta aldian behin Batasuneko ingurumenaren egoerari buruzko ebaluazio-txostenak egiten ditu.

(23) GIRÓN LARRUCEA, José Antonio, La Comunidad Europea como Organización Internacional, Centro de Estudios Ramón Areces, Madril, 1999, 115 orr. 
Tratatuak bertako Hitzaurrean barneratu zuen garapen iraunkorraren printzipioa, estatu kideek printzipio hori kontuan har zezaten beren herrien garapen ekonomikoa eta soziala sustatzeko hartuko zuten erabakian. Ikusten denez, testu berriak Batasunaren helburu nagusien artean azpimarratzen zuen garapen iraunkorra, Europaren integrazio prozesuaren helburutzat behin betiko ezarriz, eta ez bakarrik ingurumen politikaren helburutzat (24).

Bestalde, EETn barneratutako berritasunek EBren helburu gisa ezartzen zuten ingurumenaren babesa indartzea. Hala, EETren 2. artikuluan, zenbait eransketa gehitu zitzaizkion Batasunaren misioari, zeinak sustatu egingo dituen «jarduera ekonomikoen garapen harmoniatsua, orekatua eta iraunkorra», eta «ingurumenaren kalitatearen maila eta hobekuntza nabarmena». Ikusten denez, bi helburu bereizten dira: batetik, iraunkortasuna, honela ulertuta: «naturako eta ingurumeneko baliabideekin erlazionatzeko modu bat (modu "adiskidetsu" bat, esan genezake), garapen ekonomikorako beharrezko baldintza adierazten duena - gizartearen zerbitzura, jakina - eta epe luzera iraungo duena»; bestetik, «ingurumenaren hobekuntza, herritarren bizi kalitatean eta bizi mailan aurrera egiteko beharrezko baldintza adierazten duena» (25). Era berean, agindu berri bat ezarri zen, $3 \mathrm{C}$ artikulua, non espezifikoki biltzen zen «ingurumena babesteko eskakizunak Erkidegoaren politiken eta ekintzen definizioan eta egikaritzan barneratu behar dira (...), garapen iraunkorra sustatzeko helburuz bereziki» (26).

Ingurumen Politikak Titulu propio batean araututa jarraitu zuen, nahiz eta gerora XIX. Titulua (174-176. artikuluek osatua) izango zen. Amsterdameko Tratatuak barneratutako berritasunak aurrerapen nabarmena adierazi zuen politika horren demokratizazioan, gai horretarako lege-prozedura orokorra elkarrekin erabakitzekoa bihurtuko zelarik, lankidetza-prozeduraren ordez. Era horretan, Europako Parlamentuaren esku-hartze handiagoa gaitu zen ingurumenaren gaietan.

2001eko Nizako Tratatuak ez zuen aldaketarik barneratu ingurumenaren Europako politikan. Aldiz, aldatu egin zuen EBren egitura, kontinentearen ekialderantz zabaltzea ahalbidetzeko eta hurrengo urteetan hamabi herrialde Batasunaren kide izatea errazteko. Horregatik, Seigarren IEP prestatu behar izan zenean, agintariak jabetzen ziren zabalkuntza horrek baldintzatu egingo zuela Batasunaren ingurumen politika, «ingurumenarekiko errespetu gutxiagoko historia zuten herrialdeak barnean hartzean, kasu

(24) WOOD, David M. eta YESILADA, Birol A., op. cit., 172 orr.

(25) YÁBAR STERLING, Ana, «EI desarrollo sostenible, principio y objetivo común de la sociedad y el mercado, en la UE de nuestros días", Foro. Revista de ciencias jurídicas y sociales, 0 zenbakia, 2004, 82 eta 83 orr.

(26) Espezifikazio horrek hauxe adierazten zuen, EABk $130 \mathrm{R}$ artikuluaren 2. ataleko lehen paragrafoaren amaieran bilduta zuen aipamena ezabatzea. 
gehienetan Erkidegoko ia estatu gehienek praktikatutakoaren aldean» (27). Horregatik, Estatu orok Batasuneko kide izateko duen ondarea bere osotasunean barneratzeko betebeharraren barruan, bereziki azpimarratu zen Europako ekialdeko kide berriek Batasunaren ingurumen-legeria osoa barne-mailan egokitu zezaten.

Nizako Tratatua berekin ekarriko zuten negoziazioak garatzen ari ziren bitartean, Lisboako Estrategia ezagutzera eman zuen EBk, Europar Kontseiluak 2000ko martxoaren 23-24an onetsia. Plan global bat zen, helburu zuena Europa 2010erako munduko ezagutzaren ekonomia lehiakorrena eta dinamikoena bilakatzea, enpleguan, erreforma ekonomikoan eta kohesio sozialean eragina izango zuena. Hasiera batean bildu ez bazen ere, ingurumen dimentsioa 2001 eko ekainaren 15-16ko Göteborgeko Europar Kontseiluan gehitu zuten Lisboako Estrategien helburuetan, eta era horretan ezarri zen Garapen Iraunkorrerako Europako Estrategia (28).

Estrategia hura Batzordearen aldez aurreko proposamenetik abiatzen zen, Seigarren IEP gisa Europar Kontseiluak ondoren onetsiko zuen proposamenarekin batera landu zen horretatik, alegia. Horregatik, programa horretan garatuko ziren Garapen Iraunkorrerako Estrategian finkatutako helburuak: klima aldaketaren aurka borroka egitea Kyotoko Protokoloaren konpromisoak betez; garraio politika iraunkor bat zehaztea; osasun publikoarekiko mehatxuei aurre egitea; baliabide naturalak modu arduratsuago batean kudeatzea. Aldi berean, ingurumena Europako politika guztietan barneratzearen ideia azpimarratzen zen, zegozkien estrategia sektorialak garatzeko eskatuz.

Lisboako Estrategiak ordurako azpimarratzen zuen ingurumenaren erronka handientzat jo daitekeen honek hartu zuen garrantzia: klima aldaketaren aurkako borroka. Gai horrek Europako Ingurumen Zuzenbidean hartuko zuen garrantziaren erakusgarri gisa adierazi behar da 2000. urtearen hasieran Batzordeak egitura bat abian jartzea proposatu zuela, klima aldaketaren aurka borroka egiteko neurriak identifikatzera eta prestatzera zuzendua (29). Hala, Klima Aldaketari buruzko Europako Programa eratu zen, alde interesatu guztiei ahalbidetuko ziena berotegi efektuko gasen emisioak gutxitzeko politiken eta neurrien prestaketa lanetan parte hartzea.

2002ko uztailean, Parlamentuak eta Kontseiluak Seigarren IEP onetsi zuten 2002-2012 aldirako(30); azpimarratu beharra dago elkarrekin era-

(27) MUÑOZ DE BUSTILLO, Rafael eta BONETE, Rafael, op. cit., 303 orr.

(28) 2001eko ekainaren 15 eta 16ko Göteborgeko Europar Kontseilua - Presidentetzaren Ondorioak, SN 2001/1/01 REV 1.

(29) EUROPAR BATZORDEA, 2000ko martxoaren 8ko komunikazioa, «Hacia un Programa Europeo sobre el Cambio Climático" (PECC), COM (2000) 88 final, 2000.

(30) Erabakia 1600/2002/CE zk., Europako Parlamentuarena eta Kontseiluarena, 2002ko uztailaren 22koa, Europako Erkidegoko Aldizkari Ofiziala L 242/1, 2002/09/10. 
bakita onetsitako aurreneko programa izan zela. "Geroa gure eskuetan dago" izeneko programak lau jardute-eremu zehazten zituen, eta horietako bakoitzean lortu beharreko helburu bat ezartzen zen. Lehenengo eremua, erronka nagusitzat hartua, klima aldaketa zen, eta eremu horretan Kyotoko Protokoloko helburuak lortzea erabaki zen epe laburrerako xedetzat(31). Bigarrenean, naturaren eta biodibertsitatearen eremuan, helburua zen sistema naturalen egitura eta funtzionamendua babestea eta lehengoratzea, bai EBn bai munduan. Ingurumenaren, osasunaren eta bizi kalitatearen arteko erlazioari dagokionez, osasun publikoa bermatzen lagunduko duen ingurumenaren kalitate maila jakin bat lortzea ezarri zen helburutzat, kutsadura maila murriztuz giza osasunaren gainean ondorio kaltegarriak izan ez dezan. Azkenik, laugarren eremuak, baliabide naturalen eta hondakinen kudeaketan datzanak, baliabide berriztagarrien eta ez berriztagarrien kontsumoa zaintzea zuen helburu, kontsumo horrek ingurumenak jasan dezakeenaren atalasea gainditu ez dezan.

Ingurumen gaietan planteatzen diren erronkei aurre egitearren, Seigarren IEPk lege-ikuspegi soila gainditu eta horren ordez ikuspegi estrategiko bat hartzeko premia ezarri zuen. Era horretan, ekintza estrategikorako lehentasunezko bost ardatz proposatu ziren (horietako bakoitzerako ekintza espezifikoak proposatzen ziren): indarrean zegoen legeriaren aplikazioa hobetzea; ingurumena beste politika batzuetan barneratzea; merkatuarekin lankidetzan aritzea; herritarrak inplikatzea eta haien jokabideak aldaraztea; lurraldearen ordenamenduari eta kudeaketari buruzko erabakietan ingurumena kontuan hartzea.

Lisboako Estrategia abian jartzetik, 2004an, Batasunak hiru urte lehenago Göteborgen ingurumenaren arloan zehaztu zituen planak eta helburuak berrikusteari ekin zion Batzordeak. Hala, 2005eko ekainean, Europar Kontseiluak Garapen Iraunkorrerako Berrikusitako Estrategiaren oinarriak finkatu zituen, eta urtebete geroago Lisboako Estrategiarekin sinergiei etekina ateratzeko modua ezarri zen(32). Funtsezko helburuek ingurumena babestea, kohesio soziala, aurrerabide ekonomikoa eta planetako garapen iraunkorrean laguntzea izaten jarraitzen zuten. Helburu horietatik lehenak Batasunaren jarduera zehaztu zuen, hau da: "Lurraren ahalmena zaintzea bizitza forma guztiei eusteko, planetako baliabide naturalen mugak errespetatzea eta ingurumenaren kalitatearen babes eta hobekuntza maila altua bermatzea», baita «ingurumenaren kutsadura prebenitzea eta

(31) EBren kasuan, helburua zen berotegi efektuko gasen emisioak \% 8 murriztea 2008-2012 aldirako, 1990eko mailekiko. Epe luzeagorako, 2020rako, beharrezkoa izango zen nazioarteko akordio eraginkor baten bitartez emisio horiek \% 20 eta \% 40 bitartean murriztea.

(32) EBren KONTSEILUA, Revisión de la Estrategia de la UE para un desarrollo sostenible (EDS UE), 10117/06, Brusela, 2006ko ekainak 9. 
murriztea eta kontsumo eta produkzio jasangarria bultzatzea hazkunde ekonomikoaren eta narriaduraren arteko lotura hausteko".

Estrategiaren berrikuspenaren ondorioz, eguneratu egin ziren erronka nagusiak, eta bakoitzerako helburu orokor bat zehaztu zen: klima aldaketa eta gizartearentzat eta ingurumenarentzat dituen kostuak eta ondorio negatiboak mugatzea; garraio jasangarriak bermatzea; kontsumo eta ekoizpen eredu jasangarriak bultzatzea; baliabide naturalen kudeaketa hobetzea eta beren gehiegizko ustiapena saihestea; osasun publikoa sustatzea mehatxu sanitarioen aurrean; gizarte inklusibo eta solidario bat sortzea; munduan garapen iraunkorra bultzatzea. Aldi berean, Batasunaren erabakiaren arabera, estatu kideek garapen iraunkorreko euren estrategia nazionalak landu behar zituzten, eta estrategia horiek urtean bitan berrikusteko beharra ezarri zuen.

Ikusten denez, Europako ingurumen politika eta araudia zehaztuko zituzten oinarrien artean, berebiziko garrantzia hartzen zuen klima aldaketak eta bere ondorioak, eta hala ezarri ziren bere aurkako erronka eta borroka helburutzat. Beraz, Batzordeak, fenomeno horren ondorioak eta horri dagokionez ekintza baten kostuak eta onurak aztertu ondoren, klima aldaketaren aurkako borrokan Batasunaren jarduna garatu behar den eremuak ezarri zituen (33): borroka hori herrialde kutsatzaile guztietara eta inplikatutako sektore guztietara hedatzea; berrikuntza eta teknologia berrien garapena indartzea; merkatuan oinarritutako tresnak erabiltzea eta sendotzea (Batasunak barneratutako isurketa eskubideen merkataritza, besteak beste); eta klima aldaketara egokitzeko eta berau prebenitzeko ahaleginak egitea.

Lehen aipatu denez, Europako Jatorrizko Zuzenbideak eta zenbait programek ordurako zehazten zuten ingurumena babesteko eskakizunak Batasunaren politiken egikaritzan barneratu beharra direla, garapen iraunkorra bultzatzeko helburuz, batik bat. Hori bereziki nabarmena izan zen Europako energia politikari dagokionez, politika hori Tratatuetan ezarri ez bazen ere, estatu kideen arteko energiaren arloko lankidetza baten bitartez egituratu baitzen 70eko hamarkadako krisiaz geroztik. Orain arte ikusitako eboluzioaren eraginez, 1999az geroztik Europako energia politikaren ikuspegi orekatu bat hartu zen, ingurumena ere kontuan hartzen zuena, lehiakortasunarekin eta segurtasunarekin batera.

2007aren hasieran, Batasunak energia politika bat garatzeko estrategia aurkeztu zuen bi helbururekin, ingurumen politikari zuzenean lotzen zaizkienarekin: batetik, kontsumo baxuko ekonomia baten, energia seguruago, lehiakorrago eta iraunkorrago baten aldeko konpromiso irmoa; bestetik, politika horrek klima aldaketaren arazoari heltzeko balio izateko

(33) EUROPAR BATZORDEA, 2005eko otsailak 9ko komunikazioa, "Ganar la batalla contra el cambio climático mundial», COM (2005) 35, 2005. 
asmoa. Energiaren ekoizpenean eta giza kontsumoan ingurumenak zituen inplikazioak kontuan hartzearen emaitza izan zen Europako proposamena, eta beraz, ez zuen lekurik pentsatzeak «bere funtsezko osagaitzat iraunkortasuna kontuan hartuko ez duen energia politika batean, horniduraren segurtasuna eta lehiakortasuna bezalako alderdiekin - gutxienez- parekatuko ez den energia politika batean» (34).

Aipatutako energia politika berri horren oinarriak energiari buruzko 2006ko Liburu Berdean jaso ziren (35), Batasunak jardun beharreko sektoreak identifikatu zituen horretan. Oinarri horien erdiek lotura estua dute ingurumenarekin. Hala, energia konbinazio iraunkorragoa, eraginkorragoa eta anitzagoa lortzeko, energia iturri desberdinen abantaila eta desabantaila guztiak aztertzeari ekin zitzaion, eta energia iturri seguruen eta karbono-emisio baxukoen aldeko apustu argia egin zen, hau da, energia berriztagarrien aldekoa. Klima aldaketaren aurkako borrokaren ikuspegi integratua lortzeko helburuz, energiaren eraginkortasuna lortzeko premia azpimarratzen zen, energia xahutzea murriztuz eta energiaren erabilera arduratsuagoa, merkeagoa eta zentzuzkoagoa bultzatuko duten neurriak hartuz. Azkenik, energiaren arloan berrikuntza sustatzeko, ikerketa indartzearen eta areagotzearen alde egin zen apustu. Energia politika ingurumen politikari lotuta geratzen zen horrela, iraunkortasuna izango baitzen bere helburu nagusia, lehiakortasunarekin eta horniduraren segurtasunarekin batera.

2007ko urtarrilean iraunkorki ezarriko zen ingurumenaren eta energiaren arteko lotura, batik bat klima aldaketaren aurkako borrokari dagokionez. Izan ere, Batzordeak klima aldaketaren aurkako borrokaren Europako estrategia zehaztu zuen (36), eta aldi berean bere proposamena ezagutzera eman zuen Europan energiaren arloan planteatzen ari ziren erronken aurrean - bereziki klima aldaketa eta horniduraren segurtasuna Batasunean- (37). Biak onetsi zituen Europar Kontseiluak(38), eta Lisboako Tratatuarekin eremu horietan egingo zen erreforma zehaztuko zuten biek.

Era horretan, EBren alde bakarreko helburutzat finkatu zen berotegi efektuko gasen emisioak 1990. urtearekiko \% 20 gutxitzea 2020ra arte. Eu-

(34) LÓPEZ SAKO, Masao Javier, "La política energética sostenible de la Unión Europea (1)», Noticias de la Unión Europea, 322 zenbakia, 2011, 81 orr.

(35) EUROPAR BATZORDEA, Libro Verde: Estrategia europea para una energía sostenible, competitiva y segura, COM (2006) 105 final, 2006.

(36) EUROPAR BATZORDEA, 2007ko urtarrilak 10eko komunikazioa, Limitar el calentamiento mundial a $2{ }^{\circ} \mathrm{C}$ - Medidas necesarias hasta 2020 y después, COM (2007) 2 final, 2007.

(37) EUROPAR BATZORDEA, 2007ko urtarrilak 10eko komunikazioa, Una política energética para Europa, COM (2007) 1 final, 2007.

(38) 2007ko martxoak 8 eta 9ko Bruselako Europar Kontseilua - Presidentetzaren Ondorioak, 7224/1/07 REV1. 
ropar Kontseiluak gogoan hartu zuen herrialde garatuek konpromisoa hartu behar zutela, nazioarteko akordio baten esparruan, 1990. urtearekiko beren emisioak \% 30 gutxitzea 2020ra arte, eta \% 60 eta \% 80 bitartean 2050 era arte. Akordio horri azkena emanez gero, Batasunak 2020ra arteko emisioen \% 30eko murrizketa helburutzat ezarriko luke.

Europar Kontseiluak energia politikari buruzko bere iritzia ere eman zuen, klima aldaketaren aurkako borrokan zuen garrantzia ikusita, eta 2020ean lortu beharreko ondoko helburuak finkatu zituen: energiaren eraginkortasuna handitzea Batasuneko energia kontsumoaren \% 20 aurrezteko; Batasuneko guztizko energia kontsumoan energia berriztagarriek adierazten zuten portzentajea \% 20ra eramatea; garraioak eragindako gasolinaren eta gasolioaren guztizko kontsumoan bioerregaiek adierazitako portzentajea \% 10 igotzea.

\section{Lisboako Tratatua eta Europa 2020 Estrategia}

2007ko abenduaren 13an Lisboako Tratatua sinatu zuten, eta 2009ko abenduaren 1ean sartu zen indarrean; hala, Europako oinarrizko araudia EBTk eta Europar Batasunaren Funtzionamenduari buruzko Tratatuak (EBFT) -EETren ordezkoa - osatuko zuten (39), biek maila juridiko berarekin (1. art. EBT). Arrakastarik izan ez zuen Europar Batasuneko Konstituzioak jadanik jasotako berritasun gehienak ekarri zituen Tratatu berriak, eta hori argi geratu zen islatuta ingurumenaren arloan eta, gainera, klima aldaketaren aurkako borroka barneratu zuen helburu espezifiko gisa. Era horretan, gaur egun, EBren funtsezko testu juridikoek Ingurumen Politikaren legezko printzipioak biltzen dituzte, instituzioen jarduna bideratu eta mugatzen dutenak eta modu espezifikoagoan ingurumeneko ekintza programen eta horiek garatzen dituzten xedapenen bitartez arautzen direnak.

Garapen iraunkorra EBren helburu izatea ezartzen du EBTk, helburu hori "printzipio konstituzionaltzat aldarrikatzen duen» munduko eskualde bakarra izanik (40). Bere 3. artikuluan geratzen da horrela jasota, eta ikuspegi bikoitz batekin - bai barnekoa bai kanpokoa-. Izan ere, barne-merkatuari dagokionez, agindu horren 3. zenbakiak jasotzen du Batasunak "Europaren garapen iraunkorraren alde egingo du lan», eta hiru elementutan oinarrituko da: hazkunde ekonomiko orekatua, merkatu-ekonomia

(39) «Versiones consolidadas del Tratado de la Unión Europea y del Tratado de Funcionamiento de la Unión Europea", Europar Batasunaren Aldizkari Ofiziala, C 115, 2008/05/09. Lan honetan kontuan hartu da ere Eusko Jaurlaritzak egin dituen itzulpenak Herri Arduralaritzaren Euskal Erakundearen Itzultzaile Zerbitzu Ofizialaren bidez (www.habe.euskadi.eus).

(40) TORRE-SCHAUB, Marthe, "L'apport du principe de développement durable au droit communautaire: gouvernance et citoyenneté écologique», Revue du Marché Commun et de l'Union Européenne, 555 zenbakia, 2012, 89 orr. 
soziala eta «ingurumenaren babes-maila eta kalitatearen hobekuntzamaila handia». Eta, aurrerago, 5. zenbakiak adierazten du munduko gainerako herrialdeekin dituen harremanetan, Batasunak bere balioak adierazi eta sustatuko dituela, beste xede batzuen artean, "Lurraren garapen iraunkorra» lortzen laguntzea esan nahi duena.

Batasunaren helburutzat garapen iraunkorra ezartzeak, ingurumen politikaren eremua gaindituz, politika horrek Batasunaren gainerako politiken gainean izango duen eragin nabarmena adierazten du. Horri dagokionez, EBFTk espresuki jasotzen du «Batasunak politikak eta ekintzak zehaztu eta gauzatzerakoan, ingurumenaren babeserako eskakizunak sartu behar dira bertan, batez ere garapen iraunkorra sustatzeko" (11. art. EBFT). Horrek aurrerabide ekonomikoaren, justizia sozialaren eta ingurumen osasuntsu baten arteko oreka proportzionatua eskatzen zuen, batera lortu beharrekoa: «Ingurumenaren aldeko politikak positiboak izan daitezke berrikuntzarako eta lehiakortasunerako. Aldi berean, hazkunde ekonomikoa sustatzen dute, funtsezkoa helburu sozialak betetzeko» (41).

Ohi denez Europako ingurumen politikaz hitz egiten den arren, kontua da ez gaudela Batasunari esklusiboki dagokion eskumen batetik eratorritako politika baten aurrean. Ingurumen politika Batasunaren eta estatu kideen artean partekatutako eskumena bada ere (4.2. art. EBFT), aintzatetsi beharra dago guztien artean koordinazio handia dagoela, EBFTren XX. Tituluan jasotako araudi zehatzak, 191-193. artikuluek osatuak, erraztua. Dena den, eskumen partekatu bat bada ere, Batasunaren esku-hartzeak "garrantzi handia du politika aurreratuak ezartzerakoan (babes maila handikoak), oso kontzientziazio maila baxuetatik eta, ondorioz, babes maila baxuetatik abiatzen ziren herrialdeetan» (42).

EBFTren 191. artikuluak bere 1. zenbakian ingurumenaren arloko Batasunaren politikaren helburu zehatzak ezartzen ditu: ingurumenaren kalitatea zaintzea, babestea eta hobetzea; pertsonen osasuna babestea; baliabide naturalak zuhurki eta zentzuz erabiltzea; eskualdeetako edo munduko ingurumen arazoei aurre egiteko eta bereziki klima aldaketaren aurka borroka egiteko neurriak nazioartean bultzatzea. Nazioarteko neurriekin klima aldaketaren aurka borroka egiteko premia Lisboako Tratatuak gehitutako alderdia da, Batasunarentzat arazo horrek hartu zuen garrantziaren erakusgarri.

Aipatutako EBFTren 191. artikuluko 2. zenbakiak adierazitakoaren arabera, Batasunak ingurumenaren babes maila handia lortu behar du, be-

(41) EUROPAR BATZORDEA, Un medio ambiente de calidad. La contribución de la UE, OPOCE, Bruselas-Luxemburgo, 2006, 3 orr.

(42) BARBERÁN ORTí, Ramón eta EGEA ROMÁN, María Pilar, "Las Políticas de Medio Ambiente y de los Consumidores", JORDÁN GALDUFF, Josep María (koordinatzailea), Economía de la Unión Europea, Civitas, Madril, 2002, 405 orr. 
tiere kontuan hartuta Europako lurraldeko eskualde desberdinetan dauden egoera anitzak. Ikusten denez, politika honen asmoa da Batasuneko herritar guztiek ingurumen maila bera izateko duten eskubidea eta enpresek lehiakortasun baldintza beretan jarduteko duten eskubidea bermatzea; moldakortasunez, ordea, ahal den neurrian herrialde bakoitzaren zirkunstantzia desberdinak errespetatu behar baitira. Paragrafo berak ingurumen politikak oinarritzat dituen lau printzipioak adierazten ditu: zuhurtasunprintzipioa, prebentzioko ekintzak, ingurumenari egiten zaizkion erasoak sorburuan bertan zuzentzea, eta kutsatzen duenak ordaintzea (43).

Aurretik aipatu bezala, Europako araudiak ezarritakoaren arabera, ingurumena babesteko eskakizunak Batasunaren politikak definitzean eta burutzean kontuan hartu behar dira, bereziki garapen iraunkorra sustatzeko helburuz (11. art. EBFT). Horrek esan nahi du, batetik, ingurumenaren arloko helburuak eta printzipioak Batasunaren gainerako politiketan lortu eta aplikatu behar direla, ingurumen politikan egiten den bezala; eta, bestetik, ingurumen araudia ikuspegi global batez ulertu eta interpretatu behar dela, gai horri buruzko legerian dagozkion helburu eta printzipio guztiak kontuan hartuz (44).

Ingurumen politikak beste politika batzuetan izan duen integrazioa bereziki antzematen da gaur egungo Europako energia politikan, eta hori ondo geratu zen islatuta Lisboako Tratatuak ekarritako berritasunetako batean, gai horretan erregulazio independente bat barneratzean zetzan horretan. Erregulazio hori EBFTren XXI. Tituluan geratu zen jasota, hau da, ingurumen araudiaren ondoan, eta bere agindu bakarrak (194.1. art. EBFT) bi politiken arteko lotura islatzen du, Batasunaren energia politikaren helburuak ezartzen baititu «ingurumena zaindu eta hobetzeko eskakizuna dagoela kontuan izanik».

Energiaren merkatuaren funtzionamendua eta horniduraren segurtasuna bermatzeaz gain, eta energia sareen arteko lotura sustatzeaz gain,

(43) Horietako bakoitzaren esanahia identifikatzen du Batzordeak. Zuhurtasun-printzipioak adierazten duenez, ingurumen arazo sortu berri baten aztarren argirik agertuz gero, kautelazko neurriak hartu behar dira, baieztapen zientifiko osaturik ez badago ere. Prebentzio ekintzaren printzipioak adierazten duenez, ingurumena babesteko politikarik eraginkorrena ingurumenaren edozein kutsadura edo narriadura bide saihesten saiatzean datza, ekintza kaltegarri baten ondorioak erremediatu beharrean, ekintza hori gertatu eta gero eta kalteak saihestezinak direnean. Ingurumenari egindako erasoak sorburuan bertan zuzentzearen printzipioak dagokion soluziobidea berehala aplikatzea dakar berekin, erasoen ondorioak ahal den gehien neutralizatzeko eta horien progresio kontrolaezin posiblea saihesteko. Kutsatzen duenak ordaintzen du printzipioak ezartzen duenez, zehaztu egin behar dira ingurumenaren gaineko ekintza narriatzaileak, erantzukizuna berekin ekarriko duten gertakariak izan daitezkeelarik horiek, baita erregelamentazio bat egituratzea ere, ordaindu beharreko kalteak dakartzaten arau-hausteak identifikatuko dituena eta arau-haustea egotziko zaien pertsonak indibidualizatuko dituena. EUROPAR BATZORDEA, Un medio ambiente..., op. cit., 4 orr.

(44) KULOVESI, Kati, MORGERA, Elisa eta MUÑOZ, Miquel, «Environmental integration and multifaceted International dimensions of EU law: unpacking the EU's 2009 climate and energy package», Common Market Law Review, 48 zenbakia, 2011, 834 orr. 
Tratatuak Europako energia politikaren helburu gisa biltzen du «energiaren eraginkortasuna eta aurrezpena eta energia berrien eta berriztagarrien garapena sustatzea» (45). Hala, energiaren arloaren eta ingurumenaren arloaren arteko lotura estua agerian geratu da baita ere bere alderdi arauemailean Europar Batasunaren Jatorrizko Zuzenbidean (46). Are gehiago, adierazi beharra dago Batasunean politika integratua garatzen dela energiaren eta ingurumenaren arloetan, eta bi arloen arteko loturak "beharrezko erregulazio-sinbiosi bat adierazten du» (47), beraz.

Kontua da Batasunaren araugintza ordurako islatzen hasia zela aipatutako berritasunak ekarri zituzten arloen arteko lotura estua: klima aldaketaren aurkako borroka eta energia, batik bat energia berriztagarriak bultzatuz, ingurumena babesteko oso neurri lagungarria, alegia. Izan ere, 2008ko urtarrilean, Batzordeak neurri-pakete global bat argitaratu zuen klimaren babesari eta energiari buruz, eta emaitzaz garrantzi handiko legegintzako egintzak onetsi zituzten Europako Parlamentuak eta Kontseiluak (48). Zehazki, energia berriztagarriak indartzearen eta garatzearen aldeko apustuak, hornidura ekonomikoaren segurtasuna eta fidagarritasuna hobetzea helburutzat hartzeaz gain, argi utzi zuen «inoiz baino gehiago, Europan, energia baliabide berriztagarrien garapena funtsezko faktorea da klima aldaketaren aurkako borrokan» (49). Are gehiago, harrez geroztik, «energia berriztagarriak Europa mailan onetsitako energia politika berrienen funtsezko giltzarria dira, politika horiek ingurumenerantz bideratzeko, klimaren aldaketaren aurkako borrokaren nazioarteko estrategiaren esparruan" (50).

2010eko martxoaren 3an, Batzordeak jendartera atera zuen bere proposamena 2008an eztanda egin zuen nazioarteko krisi ekonomikotik atera-

(45) Alexander Gusev-ek azpimarratzen duenez, helburu hori zuzenean dago lotuta klimaren agendarekin eta, beraz, ingurumen politikaren helburuekin. GUSEV, Alexander S., op. cit., 81 orr.

(46) Gai horren inguruan, ikus MOUSSIS, Nicolas, EU Environment \& Energy Policies: Two Interwoven Legislative Areas, European Study Service, Rixensart (Belgika), 2009.

(47) LÓPEZ SAKO, Masao Javier, op. cit., 81 orr.

(48) «Energia eta klima paketea» deritzon hori ondoko legegintza-egintza hauek osatzen zuten, Europako Parlamentuak eta Kontseiluak onetsiak 2009ko apirilaren 23an (guztiak Europar Erkidegoko Aldizkari Ofiziala L 140an, 2009ko ekainaren 5ekoan): 2009/28/EE Zuzentaraua, iturri berriztagarrietatik eratorritako energiaren erabilera sustatzeari buruzkoa; 2009/29/EE Zuzentaraua, berotegi efektuko gasen emisioen eskubide-merkataritza hobetzen duena; 2009/31/EE Zuzentaraua, karbono-dioxidoaren metaketa geologikoari buruzkoa; 406/2009/EE Erabakia, Erkidegoko estatuek berotegi efektuko gasen emisioak murrizteko egin beharreko ahaleginari buruzkoa, 2020ra arte Erkidegoak bere gain hartutako konpromisoak betetzeko helburuz.

(49) EUROPAR BATZORDEA, 2009ko apirilak 24ko komunikazioa, Informe de avance sobre la energía procedente de fuentes renovables, COM (2009) 192 final, 11 orr.

(50) MORA RUIZ, Manuela, "La ordenación jurídico-administrativa de las energías renovables como pieza clave en la lucha contra el cambio climático: ¿Un sector en crisis?», Actualidad Jurídica Ambiental, 32 zenbakia, 2013, 2 orr. 
tzeko eta, hurrengo hamarkadari begira, Europar Batasunaren ekonomia prestatzeko: Europa 2020 (51). Estrategia horrek Europako merkatuaren ekonomia sozialari buruzko ikuspegi bat aurkeztu zuen oraingo hamarkadarako, eta lehentasunezko hiru eremu ditu oinarri, elkarri lotuak eta elkarri indarra ematen dietenak: hazkunde adimenduna, ezagutzan eta berrikuntzan oinarritutako ekonomia garatuz; garapen iraunkorra, karbono-maila baxuko ekonomia bultzatuz, baliabideei eta lehiakortasunari begira eraginkorra izango dena; eta hazkunde integratzailea, gizartearen eta lurraldearen kohesioa bultzatuko duen enplegu-maila handiko ekonomia suspertuz.

Eremu horietan aurrera egiteko, estrategiak bost helburu nagusi zehaztu zituen: Gure aztergaiari dagokionez, helburu horietatik hirugarrena azpimarratu behar da, «20/20/20» helburu gisa ezagutzen duguna klimaren eta energiaren arloetan. Berotegi efektuko gasen emisioak \% 20 gutxitzea - edo \% 30, hori lortzeko baldintzak ematen badira-; energia berriztagarrien proportzioaren $\% 20$ handitzea energiaren guztizko kontsumoan; eta energia kontsumoa \% 20 gutxitzea energiaren eraginkortasun handiagoa lortzeko (52).

Hazkunde iraunkorrari buruzko helburu zehatzean, Europa 2020 estrategiak ekonomia eraginkorragoa, berdeagoa eta lehiakorragoa defendatzen du. Testuak honela definitzen du «baliabideei eraginkortasunez etekina aterako dion ekonomia, iraunkorra eta lehiakorra, Europaren aitzindaritzaz baliatuko dena prozesu eta teknologia berriak - teknologia berdeak barne - garatzeko bidean, EBn sare adimendunen garapena bizkortuko duena eta gure enpresen abantaila lehiakorrak sendotuko dituena (...) eta, gainera, kontsumitzaileei baliabideen erabilera eraginkorra balioesten lagunduko diena». Helburu honen garrantzia ondorioz ekar dezakeen emaitzaren araberakoa da; izan ere, "lagundu egingo dio EBri karbono-emisio gutxirekin eta baliabide mugatuekin munduan aurrera egiten eta aldi berean eragotzi egingo ditu ingurumenaren narriadura, biodibertsitatearen galera eta baliabideen erabilera ez iraunkorra».

(51) EUROPAR BATZORDEA, 2010eko martxoak 3ko komunikazioa, "Europa 2020. Una estrategia para un crecimiento inteligente, sostenible e integrador", COM (2010) 2020, 2010. Ekainan Europar Kontseilua proposamena onartu zuen eta berea egin zuen. 2010eko ekainak 17ko Bruselako Europar Kontseilua - Presidentetzaren Ondorioak, EUCO 13/10.

(52) Hauek dira 2020rako gainerako helburuak: EBko populazioaren \% 75ak, 20-64 adin bitartekoak, enplegatuta egon beharko luke; EBren BPGren \% $3 \mathrm{I}+\mathrm{Gn}$ inbertitu beharko litzateke; eskola-uztearen portzentajea \% 10 baino txikiagoa izatea, eta belaunaldi gazteenaren \% 40ak gutxienez goi-mailako ikasketak osatuta izatea; pobreziaren arriskuak 20 milioi pertsona gutxiago mehatxatzea. Begien bistakoa da helburu horien elkarrekiko erlazioa, eta Batzordeak berak aipatzen du adibide gisa bigarren eta hirugarren helburuen arteko lotura. "Karbono-emisioak murriztea berekin ekarriko duten teknologia garbiagoetan inbertitzeak lagundu egingo dio gure ingurumenari, klima aldaketaren aurkako borrokan lagunduko du eta enpresa eta enplegu aukera berriak sortuko ditu». EUROPAR BATZORDEA, "Europa 2020...», op. cit., 11 orr. 
Hazkunde adimenduna, iraunkorra eta integratzailea lortzeko, estrategiak funtsezko ekimen bat biltzen du gai honetan. «Baliabideak eraginkortasunez erabiliko dituen Europa" deritzona, bere baliabideak eraginkortasunez eta karbono-emisio gutxirekin erabiliko dituen ekonomia baterako bidea urratuko duena, hazkunde ekonomikoa baliabideen eta energiaren erabileratik bereiziz, $\mathrm{CO}_{2}$ emisioak gutxituz, lehiakortasuna indartuz eta energia arloan segurtasun handiagoa bultzatuz (53). Hazkundearen bidera itzultzeko estrategiak ekarri zituen tresnen artean bi nabarmenduko ditugu: batetik, klima aldaketaren aurkako borroka, baliabideen erabileran eraginkortasuna hobetzea eskatzen duena, kontuan izanik gainera emisioak murrizten nabarmen laguntzeaz gain, dirua aurreztea eta hazkunde ekonomikoa bultzatzea ahalbidetuko lukeela; bestetik, energia garbia eta eraginkorra, kontuan izanik eremu horretan Europako energiaren helburuen (20/20/20) lorpenak 2020ra arteko aurrezpen nabarmen bat emaitza gisa ekartzeaz gain, berotegi efektuko gasen emisioen ageriko murrizketa adieraziko lukeela.

\section{Zazpigarren IEP eta Energiaren eta Klimaren Esparrua 2030erako}

Europa 2020 Estrategiaren ondoren, ingurumenaren arloko tresna espezifikoa, lehenik eta behin gai horri dagozkion helburuak garatu beharko lituzkeena, Zazpigarren IEP da, Seigarren Programak bere indarraldia amaitu zuenean indarrean sartu behar zuena, hasiera batean 2012ko uztailean, aurreikuspenen arabera. Dena den, Batzordeak ez zuen «Zazpigarren Programa kontuan hartu nahi, argudiatuz Europa 2020 Estrategiak eta bere ekimen enblematikoek jadanik heltzen zietela ingurumen kezkei, eta ez zegoela Programa berezi baten beharrik» (54). Horregatik, azaroan indarrean jarraitzen zuen oraindik Seigarren Programak, Batzordeak adierazi zuenez 2013ra arte, zehazki. Dena den, EBko Kontseiluak horri buruzko proposamen bat aurkezteko behin eta berriz eskatu eta gero, Batzordeak etorkizuneko Programaren oinarrizko lehenengo lerroak ezagutzera eman zituen (55).

Ingurumenari begira erronkarik handienak adierazteaz gainera, erronka haiek batera kontuan hartzeko premia aditzera ematen zen, hau

(53) Bigarren ekimena, "munduratzearen arorako industria politika» deritzona, industrian, Enpresa Txiki eta Ertainetan bereziki, pentsatuz hartu zen. Enpresek beren ekoizpen-prozesuak karbono-emisio gutxiko ekonomia batera egokitu ahal izatean datza, eta munduratzearen eta ekonomia berdearen aukerez baliatu ahal izatean.

(54) FERNÁNDEZ DE GATTA SÁNCHEZ, Dionisio, "El Séptimo Programa Ambiental de la Unión Europea, 2013-2020", Revista Aragonesa de Administración Pública, 41-42 zenbakia, 2013, 88 orr.

(55) EUROPAR BATZORDEA, New Environment Action Programme to 2020 - questions and answers, MEMO/12/908, 2012. 
da, ingurumenarekin ez ezik ekonomiarekin eta gizarte arazoekin ere lotuta zeudelako. Politika eta sektore desberdinetan integratutako ekintzak bultzatzea zen asmoa, eta politika horien artean energia zen arlo nagusietako bat, Europa 2020 Estrategia garatzen zuten tresnetan antzeman zitekeenez (56).

Urtebete geroago, 2013ko azaroan, Zazpigarren IEP onetsi zuen EBk, "Ondo bizi, gure planetaren mugak errespetatuz" izenekoa(57). Bere bitartez, onartu egiten zen ingurumena ezin zela jadanik ekonomiarekin zerikusirik ez zuen gai bat balitz bezala hartu; hala, ekonomia eraldatu beharra zegoen baliabide gutxiagorekin balio handiagoa lortzeko eta kontsumo ereduak aldatzeko. Horretarako, programak «epe luzerako ingurumen estrategia bat ezartzen du, erronka anitzei erantzuteko behar bezain moldakorra eta malgua, (...) baliabide naturalak eta oraingo eta etorkizuneko belaunaldien osasuna zainduko dituen ekonomia berde eta lehiakor baterako norabidea finkatuko duena» (58).

Programa berriak, 2014-2020 aldirako indarrean, lehentasunezko bederatzi helburu ezartzen ditu. Helburu horiek lortzeko, ingurumen politikak, oro har, oinarritzat dituen printzipioei, aurretik aipatutakoei (191.2. art. EBFT), eusten die programak.

Lehentasunezko aurreneko hiru helburuek osatzen dituzte, berez, programaren eremu tematikoak. Guztietatik lehena Batasuneko kapital naturala babestu, zaindu eta hobetzea da, eta horrek biodibertsitatearen defentsa sendotzea adierazten du, baita lurzorua eta basoetako baliabideak babesteko eta lurraren erabilera iraunkorra bultzatzeko ekintzak burutzea ere. Bigarrenak, EB ekonomia hipokarboniko eta baliabideen erabileran eraginkor bilakatzean datzanak, "20/20/20" helburua lortzeko neurriak aplikatzea eskatzen du batik bat - dagoeneko Europa 2020 Estrategian finkatua-, baita 2020tik harago klima politikan eman beharreko pausoei buruzko akordio bat lortzea ere. Hala ere, hondakinak baliabide bihurtzea ere eskatzen du, prebentzioaren, berrerabileraren eta birziklatzearen alde apustu eginez, baita baliabideen erabileran eraginkortasunaren adierazleak eta helburuak definitzea eta ekoindustriak bul-

(56) «Zazpigarren Programa, Batasunaren ingurumen politikak berrogei urtetan izandako lorpen garrantzitsuetan ez ezik, eremu horretako ekimen estrategiko berri batzuetan ere oinarritzen da, baita, katastrofismorik gabe, oso itxaropentsua ez den agertoki baterako ekonomia eta gizartea prestatzen saiatzen diren beste batzuetan ere, argi eta garbi, eta ñabardura iraultzailerik gabe, karbono-emisio baxuko ekonomia baten alde apustu eginez, bestelako energia eredu batekin eta garrantzi handiko aurreikuspenekin gai hauetan: baliabideak, energia, energia berriztagarriak, biodibertsitatea, eko-berrikuntza, garraioak eta abar.» FERNÁNDEZ DE GATTA SÁNCHEZ, Dionisio, op. cit., 93 orr.

(57) Erabakia 1386/2013/EB zk., Europako Parlamentuarena eta Kontseiluarena, 2013ko azaroaren 20koa, Europar Batasuneko Agiri Ofiziala L 354.

(58) EUROPAR BATZORDEA, Un medio ambiente sano y sostenible para las generaciones futuras, EBko Argitalpen Bulegoa, Luxenburgo, 2013, 15 orr. 
tzatzea ere. Hirugarren ekintza eremua ingurumenari dagokionez Batasuneko herritarrak babestea da, giza osasunerako eta ongizaterako ingurumen presioetatik eta arriskuetatik babestea, eta horretarako, kutsadura atmosferikoa eta akustikoa murrizteko konpromisoak ezartzen ditu programak.

Laugarrenetik zazpigarrenera bitarteko lehentasunezko helburuek helburu tematikoak burutzeko esparru instrumentala osatzen dute; haiek gaitu eta errazten dituzten helburuak dira, nolabait. Lehenik (lehentasunezko laugarren helburua), Batasuneko ingurumen legeriaren onurei ahalik eta etekin handiena ateratzea da asmoa, legeria horren aplikazioa hobetuz, hain zuzen ere. Bigarren (lehentasunezko bosgarren helburua), Batasuneko ingurumen politikari buruzko ezagutzaren eta informazioaren oinarria hobetzea lortu nahi da, eta horrekin batera, ingurumeneko aldaketen ikerketa zientifikoak, segimenduak eta informazioak ezagueraoinarri bat ekartzea, Europako politikei ingurumenaren egoera egokiro ulertzea ahalbidetuko diena. Hirugarren (lehentasunezko seigarren helburua), klimari eta ingurumenari dagokien politikan inbertsioak ziurtatzeko, besteren artean, beharrezkoa izango da kutsatzen duenak ordaintzen du printzipioa era sistematikoago batean aplikatzea edo erabaki zehatzak hartzea, besteak beste EBren aurrekontuaren \% 20 gutxienez klima aldaketa murriztera eta egokitzera bideratzea. Laugarren (lehentasunezko zazpigarren helburua), EBren ingurumen politikaren barruan Europako Akta Bakarretik abiatuta aldarrikatutako xedeetako bat biltzen $\mathrm{da}$, hau da, ingurumenari dagozkion gaiek beste arlo batzuetan, hau da, nekazaritza, arrantza, garraio eta, bereziki, energia politiketan integrazio handiagoa izatea.

Azkenik, lehentasunezko azkeneko bi helburuak, helburu horizontal gehigarritzat hartzen dira, tokiko, eskualdeko eta munduko erronkei erantzutea dutelako asmotzat. Zortzigarrenak hiriak iraunkorragoak izan daitezela lortzea du helburua, batez ere hirien diseinuari eta plangintzari dagokienez. Bederatzigarrenak, aldiz, mundu mailan finkatzen ditu ingurumenari eta klimari lotutako erronkak, eta horretarako ezinbestekoa da ekimen globalen esparruan EBk beste herrialde eta eskualde batzuekin lankidetzan jardutea.

Paradoxikoki, Batzordearen esku geratu ohi den zeregina bereganatuz, EBko Kontseilua izango da ekintza programa berriak Europa 2020 Estrategiaren iraunkortasunaren alderdia bultzatzeko beharraz ohartaraziko duen erakundea (59). Izan ere, 2014ko urrian, Zazpigarren IEP indarrean sartu eta handik hamar hilabetera besterik ez, Ingurumen Kontseiluak ezagutzera eman zuen Europa 2020 Estrategiaren ingurumen dimentsioa berresteari eta indartzeari buruzko bere kontsiderazioa, bere-

(59) EBko KONTSEILUA, Dimensión ecológica del Semestre Europeo y la Estrategia Europa 2020 Revisión intermedia, 14200/14 Dokumentua, 2014/10/21. 
ziki hazkunde berderako baliabideen erabilera eraginkorra hobeto integratuz eta ekonomia zirkularraren printzipioak eta enplegu berdearen ahalmena bultzatuz (60).

2014ko urtarrilean, «20/20/20" helburuaren lorpen partzialak aurkeztu zituen Batzordeak 2030era begira klimaren eta energiaren politiketarako esparru berri baterako proposamen baten esparruan(61). Batzordearen iritziz, Europa 2020 Estrategian ezarritako helburuaren betearazpenean nabarmen aurrera egin ahal izango zen 2030erako helburu espezifikoak eremu horretan zehaztuz. Ondoren ikusiko dugunez, energia politika baliatzeak, klima aldaketaren aurkako borrokaren tresna eraginkor gisa, lagundu egiten du ingurumena babesten.

Eta, izan ere, ondo bideratuta zegoen "20/20/20" helburuaren betearazpena: 1990aren aldean, 2012an berotegi efektuko gasen emisioak \% 18 murriztu ziren eta 2020an murrizketa hori \% 24koa izatea aurreikusten zen, eta \% 32koa 2030ean; energia berriztagarrien kuota \% 13 gehitu zen 2012an, energiaren azken kontsumoarekiko proportzioan, eta 2020an \% 21 era arte gehitzea aurreikusten zen, eta \% 34ra arte 2030ean; EBk elektrizitatearen \% 44 inguru iturri berriztagarrietatik sortutakoa izatea lortu zuen (energia hidroelektrikoa izan ezik) 2012aren amaieran; EBko ekonomiaren energi intentsitatea \% 24 murriztu zen 1995 eta 2011 bitartean, eta karbono intentsitatea \% 28 gutxiagotu zen.

Europar Kontseiluak «Klimaren eta energiaren gaineko jarduketa esparrua 2013ra arte" onetsi zuen 2014ko urrian (62), eta bertan EBren helburu propiotzat hartu zituen Batzordeak proposatutako helburuak. Lehenik, EBren helburu lotesletzat finkatu zen berotegi efektuko gasen emisioak \% 40 gutxienez murriztea 2030erako, 1990eko balioekiko. Bigarren, helburu lotesle gisa baita ere, energia berriztagarrien kuota gutxienez \% 27koa izatea ezarri zen, 2030eko EBren guztizko energia kontsumoaren barruan. Hirugarren, EB mailan, 2030ean energiaren eraginkortasuna gutxienez \% 27 hobetzea adieraziko duen helburua finkatu zen, 2020a baino lehen berrikusiko dena, ahal izanez gero \% 30era iristeko (63). Gainera, Europar Kontseiluak adierazi zuenez, berebiziko garrantzia du energiaren barne-merkatu bat gauzatzeak, bete-betean jardungo duena eta erabat konektatuta

(60) Gai horren inguruan, ikus PÉREZ DE LAS HERAS, Beatriz, "La gestión eficiente de recursos en la Unión Europea: alcance e impacto de la normativa europea para una economía más sostenible y circular", Revista de Derecho Comunitario Europeo, 55 zenbakia, 2016, 781-817 orr.

(61) EUROPAR BATZORDEA, 2014ko urtarrilaren 22ko komunikazioa, Un marco estratégico en materia de clima y energía para el período 2020-2030, COM (2014) 15 final, 2014.

(62) 2014ko urriaren 23 eta 24ko Bruselako Europar Kontseilua - Presidentetzaren Ondorioak, EUCO $169 / 14$.

(63) Bai bigarren helbururako bai hirugarrenerako, estatu kideek euren helburu nazionalak ezarri ahal izango dituzte, EB osoarentzako helburu orokorrak baino jasoagoak izango direnak. 
egongo dena (64); eta horretarako, EBko herrialdeen artean \% 15eko elektrizitate interkonexioa ezarri zen helburutzat 2030erako.

2030 erako "40/27/27» helburu-pakete berri hori asmo handikotzat hartu zuen EBk berak. Hala eta guztiz ere, 2020rako «20/20/20» helburuen betearazpen maila ikusita, Batzordeak berak 2014ko urtarrilean ezagutzera emana eta goian dagoeneko adierazi duguna, ez dirudi asmo handiko helburuak direnik ez eta gehiegizko zailtasuna dakarten ahalegin gehigarririk eskatzen dutenik ere. Izan ere, ezarritako helburuak ondokoaren emaitza izan ziren: «oreka politikoa (...) ingurumenaren aldeko erabateko jarrera erakusten dutenen eta ekonomiaren lehiakortasunean izango duen inpaktuaz gehiago kezkatzen direnen artean» (65). Bestetik, elektrizitatearen sektoreko industri elkarteek eta enpresek antza izan duten gehiegizko eragina kritikatu izan da, bereziki 2030erako energiaren eta klimaren esparrua berekin ekarri zuen kontsulta eta gogoeta aldian, Batzordeak, bere proposamenean, energiaren enpresa handiak azken urteetan egiten aritu izan diren eskaeretatik askori jarraitu izanagatik(66).

2015ean, Energiaren Batasunerako estrategia sustatu zuen EBk, Batzordeak otsailean aurkeztutako proposamenetik abiatuta (67). Bere helburua zen «klimaren arloko asmo handiko politika batean oinarrituta, energia segurua, iraunkorra, lehiakorra eta eskuragarria» eskaintzea. Europako energia sistema integratua du xedetzat, «non mugetan zehar aske mugituko den energia, lehiakortasuna eta baliabideen ahalik eta erabilera onena oinarri hartuta, EBren mailako energia merkatuen erregulazio eraginkor batekin (...) ekonomia iraunkorra, hipokarbonikoa eta klimarekiko errespetu-

(64) 2012an, Batzordeak energiaren barne-merkatua 2014rako gauzatzea proposatu zuen; ezin izango zen halakorik lortu, ordea, estatu kide ugari atzeratu egin baitziren Europako araudia euren lekuetan ezartzeko eta aplikatzeko garaian. EUROPAR BATZORDEA, 2012ko urriaren 3ko komunikazioa, Acta del Mercado Único II - Juntos por un nuevo crecimiento, COM (2012) 573 final, 2012. Helburua ezarrita bazegoen ere, nabarmena zen «Estatuek ez dute energiaren arloan beren subiranotasuna galdu nahi eta, beraz, energiaren merkatuaren jarduna bermatzearen helburua eta energia sareen interkonexioa sustatzekoa, formalagoak eta teorikoagoak dira, praktikoak eta errealak baino». PÉREZ DE LAS HERAS, Beatriz, "Las políticas de seguridad energética en la Unión Europea y los Estados Unidos: desafíos globales y compromisos comunes en la transición hacia un modelo energético más sostenible", Revista de Derecho Comunitario Europeo, 47 zenbakia, 2014, 23 orr.

(65) ARANZADI, Claudio, "UE 2030: objetivo clima y energía», Política Exterior, 29 liburukia, 163 zenbakia, 2015, 46 orr.

(66) Argudio horren arabera adierazten denez «klimaren helburuei uko egiteko premiaren ideia inposatu da industriaren lehiakortasuna bultzatzearren». MORENO REGAÑA, Ana, "Hegemonía y capital transnacional en la Unión Europea. El marco para el clima y la energía», Relaciones Internacionales, 31 zenbakia, 2016, 107 orr.

(67) EUROPAR BATZORDEA, 2015eko otsailaren 25eko komunikazioa, Estrategia Marco para una Unión de la Energía resiliente con una política climática prospectiva, $\operatorname{COM(2015)~} 80$ final. Europar Kontseiluak martxoan onartu zuen dagokion konpromisoa. 2014ko martxoaren 19 eta 20ko Bruselako Europar Kontseilua - Presidentetzaren Ondorioak, EUCO 11/15. 
tsua izango den aldetik». Hortaz, agerikoa da energiaren eta ekintza klimatikoaren arteko lotura konstante bat dela dagoeneko EBren barruan.

Aurreikusitako jarduketa-dimentsioetako batzuek 2030erako energiaren eta klimaren esparruan jadanik finkatutako helburuak dakartzate. Nabarmentzekoa da ekonomiaren karbonogabetzea, batetik, EBn klimaren arloko asmo handiko politika bat eskatzen duena, berotegi efektuko gasen emisioak 2030erako gutxienez \% 40 murriztetik hasita, 1990eko mailen aldean; eta bestetik, energia berriztagarrien aldeko apustu argia eskatzen duena, zehazki, 2030ean EBn kontsumitutako energia berriztagarriaren kuota gutxienez \% 27ra igotzea. Dagoeneko adierazi bezala, oso nabarmena da helburu horiek ingurumenaren zaintzan izan behar duten ondorio positiboa.

\section{Ondorioak}

Kutsadurak ez du mugarik ezagutzen eta, beraz, ezin zaio bere kontrolari hertsiki politika nazionaletatik heldu. Europako oinarrizko ingurumen araudia ordenamendu juridiko erkide bat izateak dakartzan onuren adibide bat da, bere aplikazioak helburu erkide bat lortzea errazten baitu, hau da, garapen iraunkorra eta, oro har, Europako espazio partekatu bat sendotzea sustatzen du gainera.

Merkatu erkidearen ezaugarriek Europako Erkidegoek oinarrizko arau batzuk ezartzea eskatzen zuten, ingurumen araudi nazionalek merkatu erkidearen lehiakortasun askearen aurkako egoerak sorraraztea eragozteko. Jatorrizko Tratatuetan bildutako erregulaziorik ezean, Tratatu aldarazleak izan dira Europar Batasuneko gaur egungo ingurumen politika itxuratu dutenak. Jatorrizko Zuzenbidean gai hau barnean hartu izanak politika erkide gisa egituratzen du, gai honen eskumena estatu kideekin partekatzen bada ere. Hazkunde ekonomikoa ingurumenaren babesari lotu izanak ekarri ditu aurrerapen garrantzitsuenak, garapen iraunkorra Batasunaren oinarrizko helburu gisa ezarriz, baita Batasunaren gainerako politikak eta ekintzak definitzean eta burutzean helburu hori integratu izanak ere.

Orain indarrean dauden EBTk eta EBFTk ildo horri jarraitzen diote eta oinarrizko ingurumen erregulazioa biltzen dute, Europako instituzioek eta estatu kideek hartzen dituzten xedapenen oinarri izanik beren garapenerako. Garapen horretan, funtsezko elementuak dira Ingurumen Ekintza Programak eta horietatik eratorritako estrategiak. Europa 2020 Estrategia, Zazpigarren IEP eta klimaren eta energiaren esparrua 2030rako dira berrienak. Guztien asmoa da, besteak beste, datu adierazgarri hauei erantzutea: Europako herritarren \% 60 ingurumena babesteko garaian Europar Batasunak estatu kideekin batera jardutearen alde dago, herrialdeek bakarka jardun beharrean; Europako herritarren \% 77 ingurumena babes- 
teko Europar Batasunaren legeak beharrezkoak direlaren ideiaren alde dago; eta Europako herritarren \% 79 Europar Batasunak estatu kideetan ingurumenari buruzko legeak era egokian ezartzen direla egiaztatzearen alde dago (68).

Ingurumenari dagokionez, lan honetan aztertutako EBren oinarrizko araudia zehazten duten gidalerroen eta printzipioen eboluzioak aukera ematen du ondorioztatzeko hazkunde iraunkorraren kontzeptua giltzarri bat dela, funtsezkoa garapen ekonomiko orekatura bideratzen gaituen neurriak hartzeko planteamenduak zehazterakoan. Horretarako, gaur egun, emisio kutsatzaileen murrizketan, energia kontsumoan energia berriztagarrien presentzia areagotzean eta energia eraginkortasun handiagoaren lorpenean oinarritzen da EBren jarduna. Izan ere, ingurumenaren arloko erronkarik handiena klima aldaketa delako eta fenomeno horren aurkako borrokaren tresna eraginkorrena energia politika delako.

Trabajo recibido el 4 de mayo de 2017

Aceptado por el Consejo de Redacción el 26 de mayo de 2017

(68) EUROPAR BATZORDEA, Special Eurobarometer: Attitudes of European Citizens towards the Environment, 416 zenbakia, 2014, 27 orr. 
LABURPENA: Ingurumen Zuzenbidearen eremuan, Europar Batasun osoaren oinarrizko araudia Europako Jatorrizko Zuzenbidean ezarritakoaren arabera dago zehaztuta, garatu beharreko helburuek eta printzipioek ezartzen dituzten tresnekin batera, Europako ingurumen sistema juridikoaren gailurra osatuz, ordenamendu nazionalen gainetik lehentasuna izatean. Lan honek ingurumen gaietan indarrean dagoen Europako araudiaren oinarrien garapena eta eboluzioa aztertzen ditu. Horretarako, Tratatuak, ekintza programak, eta estrategia nagusiak aztertu dira, ingurumenaren arloan hartutako aurrenetako erabakietatik gaurdaino.

GAKO HITZAK: Europar Batasuna. Ingurumen Zuzenbidea. Garapen iraunkorra. Europako ingurumen politika.

RESUMEN: En el ámbito del Derecho ambiental, la normativa básica en el conjunto de la Unión Europea viene determinada por lo establecido en el Derecho Originario europeo, que junto a los instrumentos que establecen los objetivos y principios a desarrollar, forman la cúspide del sistema jurídico ambiental europeo, al primar sobre los ordenamientos nacionales. El presente trabajo analiza el desarrollo y la evolución de los fundamentos de la normativa europea vigente en lo que respecta al medio ambiente. Para ello, se estudian los Tratados, los programas de acción, y las estrategias principales desde las primeras decisiones en materia medioambiental hasta la actualidad.

PALABRAS CLAVE: Unión Europea. Derecho ambiental. Desarrollo sostenible. Política medioambiental europea.

ABSTRACT: In the area of environmental law, the basic legislation in the European Union is determined by the European Origin Law, which conforms the apex of the European environmental legal system, together with the instruments establishing the objectives and principles to be developed, and it is situated above national regulations. This paper analyzes the development and evolution of the fundamentals of the current European legislation on the environment. To this end, the Treaties, the action programs, and the main strategies are studied from the first environmental decisions to the present.

KEYWORDS: European Union. Environmental Law. Sustainable development. European environmental policy. 